Journal of Teacher Education for Sustainability, vol. 18, no. 1, pp. 95-110, 2016

\title{
Educational Action Research to Achieve the Essential Competencies of the Future
}

\author{
Jānis Kapenieks \\ Riga Technical University, Latvia
}

\begin{abstract}
This article analyses the conformity of the educational action research (EAR) process for the improvement of selected competencies that will be necessary in the near future for each active and responsible person. The most requested competencies in the near and midterm future are determined in accordance with near future structural requirements of labour demand, determined by international organoizations.

The contribution is based upon the outcomes of the action research carried out in the internet environment, by Bachelor students majoring in information technologies at Riga Technical University, Latvia. Working in groups, they supplemented each other's ideas, developing living theories.

The content analysis of the students' supplementary submissions and living theories was carried out to identify the features indicating the development of student actions towards the improvement of the most necessary competencies in the near future.

To accomplish the objective of action research, at first, the most requested competencies in the near and midterm future were determined. Then the changes of the features, mentioned during the three action research cycles were identified. Finally, the most important features of the students' actions indicating the development of two of key competencies, namely, Novel and adaptive thinking and Design Mindset, were identified. Perfection of referred competencies is viewed as the substantial part of education for sustainable development (ESD). The conclusions were drawn about the development of students' competencies according to the future needs identified during the action research process on the internet.
\end{abstract}

Keywords: e-learning, action research, competencies, collaborative learning, adaptive thinking

\section{Introduction}

The theoretical foundation of the study is the education philosophy of the American philosopher, psychologist and education reformer John Dewey (Dewey, 1916) which foreshadowed action research. The EAR (educational action research) is based on the theoretical studies of K. Lewin (Lewin, 1946), B. Dick (Dick, 2009) and other followers of J. Dewey. A significant component of the theoretical foundation is the theoretical 
studies of B. Glaser and A. Strauss - the developers of the grounded theory and methodology based on data and differ from the traditional research methods (Glaser, 1967). J. Whitehead (Whitehead, 2009) suggested that the grounded theory should be included into action research and developed the idea of the grounded theory into a living theory rooted in phenomenology - in subjective perception, experience and reaction. The grounded theories and the living theories are practical theories, the possibilities of including them into action research for improving the existing situation have been theoretically investigated by Kevin Barge (Barge, 2008). In the framework of sustainability, outcomes of the research were compared with research by I. Salite (I. Salite, 2008; I. Salite, Mičule, I., Kravale, M., Iliško, Dz., Stakle, A., 2007) and Dz. Iliško (Iliško, 2007) who investigated action research in education exhibiting a holistic approach and emphasizing educational situation in Latvia. Educational action research is related to the novel and adaptive thinking of its participants. Its various manifestations are essential for the present study.

The study has also used A. Kapenieks' research on the importance of information and communication technologies in the development of the knowledge society paradigm (Kapenieks, 2009) has been also made use of. For the analysis of the cognitive processes, B. Bloom's (Bloom, 1956) taxonomies have been applied and compared with the theoretical studies of five-step model of collaborative e-learning performed by G. Salmon (Salmon, 2010). Grundspenkis and A. Anohina's research on intelligent, ICT-based learning systems (Grundspeṇkis, 2005), as well as I. Slaidiņš' and G. Štāle's research on e-learning solutions in education (Štāle, 2005) have been also employed.

The e-learning environment design and the interface design have been elaborated on the basis of R. Clark's and R Mayer's theories of the architecture of an e-learning environment and a user - friendly interface design enhancing the cognitive processes (Chapnick, 2005; Clark \& Mayer, 2011). E-learning environment is of high importance in the study and it is designed to favour the development of creative thinking skills and constitutes the most signifficant aspects of learning and at the same time determines efficient learning environment. Such learning environment aims towards sustainable development, complementing awareness of learning goals, personal meaningfullness and networking to achieve the core process of the direction - "action and reflection" (Grišāne, 2008). In the study the author has identified influence of students' EAR to the development of selected competencies that will be necessary in the near future and midterm future for competitiveness in the labour market.

The goal of the study is identification of the mutual student influence between first-year Bachelor syudents majoring in information technologies, who acuire part of the study course Business Planning for the Open Market by EAR in internet environment. The study analyses the group work that promotes acquisition of future competences novel and adaptive thinking and design mindset. The author has identified design mindset evaluation parameters and assessed performance of students according to competence. Students' mutual influence in groups has been expected and author evaluated it as well.

\section{Competencies for the Future}

Educational systems of many countries nowadays encounter new challenges - to discover the successful solutions for the creation of preconditions of the knowledge society. According to the European e-Competence Framework, are defined as a combina- 
tion of knowledge, skills and attitudes appropriate to the context. Competencies are closely linked to the person's ability to make decisions in the context and framework of knowledge and skills. Knowledge as the main value is the keystone of the new paradigm and identification. The identification, development and evaluation of basic competencies are the most substantial task of educational systems in the new educational paradigm. The search for such solutions has also generated wide discussion on a political level as well. Research of the European Commission demonstrates that the service oriented knowledge intensive economy is replacing the traditional industrial and agricultural economy (Cedefop, 2008). Research-based forecast shows a substantial increase of the workforce in occupations requiring innovation-oriented competencies, appropriate to levels 5 and 6 of the International Standard Classification of Education (ISCED) (UNESCO, 2011) and levels 6, 7 and 8 in the Framework for Qualifications of the European Higher Education (EQF) (EC, 2008a). In the near future structural polarization of labour demand will take place, and the demand for workplaces will increase on the highest and lowest levels of and demand for workplaces on the highest and lowest levels EQF.

Continuous updating of competencies corresponds to the "learning society" model as a signifficant component of education for sustainable development (ESD). Awareness of importance to develop learners' competencies in order to meet present and future intellectual and professional needs promotes efforts to find new paths for a better future as a substantial component of ESD (UNESCO, 2011). Competencies for future are interconnected and important to most of the key drivers of the development of the labour landscape (Davies, 2011), encompassing values and attitudional changes, promoting values and ethics through education at higher levels to make an impact on people's lifestyles, behaviours, helping to build sustainable future (Kostuolas - Makrakis, 2010)

Frequently employers reproach universities for their inability to provide students with the necessary skills and knowledge required in the workplace. Such reprehension is caused by the inability of graduates to promptly acquire knowledge and the skills to master new technologies necessary for modern industries.

Policymakers are trying to define knowledge and skills, as a substantial part of competencies, and promote the involvement of individuals in the labour market. Above all, such efforts are increasing during crises, when competencies are becoming the cornerstones of economic growth (Ferrari, 2009). Some of defined skills are relevant to jobs and occupations rather than the current ones. These skills may also have been acquired through non-work or leisure activities or through participation in education or training (ELGPN, 2014). These are transversal skills, - accepted as most suitable for new workplaces. Such skills are problem solving, self-management and analytical skills (EC, 2008). In the perspective of life-long learning European Commission has identified eight key competencies to develop for personal fulfilment, development, social inclusion, active involvement and employment. These competences are transversal and include: communication skills in native language; communication skills in foreign languages; mathematical competence and basic competences in science and technology; digital competence; social and civic competences; sense of initiative and entrepreneurship; cultural awareness and expression; learning to learn. (EC, 2008).

Within the framework of ATC21S project managed by the University of Melnbourn, 250 researchers from 60 institutions conducted research on the most required transversal skills in the $21^{\text {st }}$ century: ways of thinking - creativity, critical thinking, problem-solving, 
decision-making, metacognition; ways of working - communication and collaboration, tools for working - information literacy, ICT literacy, ways of living in the world citizenship locally and globally, life and career, personal and social responsibility (Binkley, 2012).

Within the framework of the research conducted by the stakeholders of the Institute for the Future (IFTF), the Delphi technique was used to analyse the key drivers that would reshape the lansResearch of The Institute for the Future (IFTF) conducted at the University of Phoenix Research Institute used the Delphi technique to analyzed key drivers that will reshape the landscape of work and to identify the key skills needed for next 10 years. The drivers are as follows:

1. Extreme longevity, changing principles of career and education,

2. Rise of smart machines and systems - workplace automation replaces human workers in repetitive works,

3. Computational world that makes the world a programmable system,

4. New media ecology, communication tools requiring literacies beyond text,

5. Superstructured organizations as new social technologies, driving new forms of production and value creation,

6. Global interconnectivity and an increasing globally connected world putting adaptability and diversity at the center of organizational operations. (Davies, 2011).

Particular skills will be necessary to master in order to support each driver. Table 1 demonstrates skills of the next decade and the appropiriate key driver, reshaping demand for works, according to IFTF research.

Table 1

Competences and Key Drivers of Development (Davies, 2011)

\begin{tabular}{|c|c|c|c|}
\hline \# & Skill & Explanation & $\begin{array}{l}\text { Supported } \\
\text { key driver }\end{array}$ \\
\hline 1 & 2 & 3 & 4 \\
\hline 1 & Sense-making & $\begin{array}{l}\text { ability to determine the deeper meaning or significance } \\
\text { of what is being expressed }\end{array}$ & 2 \\
\hline 2 & $\begin{array}{l}\text { Social } \\
\text { intelligence }\end{array}$ & $\begin{array}{l}\text { ability to connect to others in a deep and direct way, to } \\
\text { sense and stimulate reactions and desired interactions }\end{array}$ & 2,6 \\
\hline 3 & $\begin{array}{l}\text { Novel and adap- } \\
\text { tive thinking }\end{array}$ & $\begin{array}{l}\text { proficiency at thinking and coming up with solutions and } \\
\text { responses beyond that which is rote or rule-based }\end{array}$ & 2,6 \\
\hline 4 & $\begin{array}{l}\text { Cross-cultural } \\
\text { competence }\end{array}$ & ability to operate in different cultural settings & 5,6 \\
\hline 5 & $\begin{array}{l}\text { Computational } \\
\text { thinking }\end{array}$ & $\begin{array}{l}\text { ability to translate vast amounts of data into abstract } \\
\text { concepts and to understand data-based reasoning }\end{array}$ & 3,4 \\
\hline 6 & $\begin{array}{l}\text { New media } \\
\text { literacy }\end{array}$ & $\begin{array}{l}\text { ability to critically assess and develop content that uses } \\
\text { new media forms, and to leverage these media for } \\
\text { persuasive communication }\end{array}$ & 4,5 \\
\hline 7 & $\begin{array}{l}\text { Transdiscipli- } \\
\text { narity }\end{array}$ & lability to understand concepts across multiple disciplines & 1,3 \\
\hline 8 & Design mindset & $\begin{array}{l}\text { ability to represent and develop tasks and work processes } \\
\text { for desired outcomes }\end{array}$ & 3,5 \\
\hline
\end{tabular}


Sequel to Table 1.

\begin{tabular}{lllc}
\hline 1 & \multicolumn{1}{c}{2} & \multicolumn{1}{c}{3} & 4 \\
\hline 9 & $\begin{array}{l}\text { Cognitive load } \\
\text { management }\end{array}$ & $\begin{array}{l}\text { ability to discriminate and filter information for impor- } \\
\text { tance, and to understand how to maximize cognitive } \\
\text { functioning using a variety of tools and techniques }\end{array}$ & $3,4,5$ \\
\hline 10 & $\begin{array}{l}\text { Virtual colla- } \\
\text { boration }\end{array}$ & $\begin{array}{l}\text { ability to work productively, drive engagement, and } \\
\text { demonstrate presence as a member of a virtual team }\end{array}$ & 5,6 \\
\hline
\end{tabular}

Studies of different authors and organizations (Binkley, 2012; Davis, 1999; EC, 2008; Ferrari, 2009) demonstrate the growing importance of transversal competencies necessary to most of future occupations and jobs that may have been acquired through non-work or leisure activities or through participation in education or training. The number of professions is growing, at the same time numbers of required employeers is decreasing. Most people can acquire speciffic professional competencies "by doing" at work. For most of them could be acquired on workplace "by doing". Each competence of the above mentioned studies cannot be viewed in isolation from other competencies. Holistic perspective means that all mentioned competencies are of importance for personal fulfilment, development, social inclusion, active involvement and employment. Competencies are also interconnected. Thus, novel and adaptive thinking, as a construct of creativity, cannot be realized without other skills. Design mindset and virtual collaboration are of highest importance. These competencies will have highest importance in future occupations. Holistic view allows viewing competences as a whole, but it does not mean impossibility to evaluate each competence apart. Novel and adaptive thinking and design mindset, closely linked to creativity the author found as very substantial.

\section{Characteristic Parameters of Competencies}

\section{Assessment of Learning Outcomes}

This chapter describes assessment of learning outcomes, action research process, competence assessment parameters and way of evaluation. Parameters for evaluation of creativity, as a substantional component of creativity, are described. Correlations of creativity parameters with final assessment of the study course Business Planning for the Open Market are demonstrated and analysed.

\section{Action Research in the Study Course}

E-learning has been used for several years within the study course Business Planning for the Open Market at Riga Technical University. Project-based learning is used for knowledge acquisition. Each student must create and justify the balance sheet within the framework of business planning for his/her own enterprise for a period of three years. The students' realised three action research cycles and constructed personal theory, as a tool for the creation of personal knowledge.

The e-learning environment of the course is incorporated in the portal of Riga Technical University portal, designed by the open source MOODLE software. It easily interoperates with other resources. Forms for action research in the group are designed in the Google Disc facilities. The students perform three learning cycles and create three living theories. They work in groups of five students. The students evaluate each other's 
plan in accordance with the basic requirements for the content of the plan. Each of the learning cycles starts with the identification of the problem to be solved. The next step is the construction of the student's personal living theory, which is communicated to the group (network). This theory will be updated during the following learning cycles. The construction of the living theory is based on the rethinking of personal beliefs, experiences and interests. Communication with other individuals introduces different experiences in the theory, leading to discourse. At the end of each learning cycle, living theory is analysed and corrected, if necessary. The teachers'/consultants' role is substantial during the correction period. The e-learning environment provides the function of stimulus. It influences the progress of ongoing action and provides the opportunity for effective monitoring of reactions (reflections). The e-learning environment becomes a valuable functional component for action research as a tool for organizing the construction of living theories.

During one semester, 214 RTU Bachelor students from 10 academic groups during one semester participated in action research. 177 students performed 2 cycles of creating the living theory, and 148 students participated in all the three cycles. In each cycle, they were divided into groups of 4 to 6 students according to the order of filling in the MS Excel sheet. Each group worked on a common document and each student created the living theory in collaboration with two group members. Upon completing the study course, 100 students voluntarily participated in a poll on the course.

\section{Assessment of Creative Thinking}

Evaluation of creativity. Assessment of student's creativity and novella and adaptive thinking as a construct of creativity during learning process gives an opportunity to improve teaching and learning quality. Contemporary knowledge assessment methods, however, do not take into account the creativity of the learner (NACCCE, 1999).

Although the concept of creativity is widespread in educational literature, but rarely it is defined (Ferrari, 2009). More common definition of creativity - ability to create of valuable novelty (Cohen, 1999). Guilford (Guilford, 1967) expands definition in framework of divergent thinking: divergent thinking creates new ideas from existing information, emphasizing guarantees of outcome. The above mentioned definition includes three approaches: creativity as the charastiristic of personality (Guilford, 1967; Koestler, 1964; Sternberg, 1999), creativity as process (Amabile, 1998; Oldham, G., 1996), creativity as outcome of crative activity (Amabile, 1998; Bebre, 2003; Lefrançois, 2000). Creativity plays an important role according to the constructivist approach: creativity is construction of meaningful knowledge (Runco, 2003). Craft (Craft, 2005) considers creativity as knowledge creation form in learner centered pedagogical discourse with active role of knowledge creation and with auditorium accepted experience, judgements and ideas (Williamson, 2009). Such approach is the basis of EAR study.

According to the constructivist approach, comprehension is developed by reflection and searches for valuables are the way to create links between previous and newly created knowledge. Comprehension is a form of creation of sense and it is creativity as well (Craft, 2005).

The objectives to be achieved by educational action research play an important role in assessment (Beghetto, 2005; Simplicio, 2000). The two types of objectives are performance and mastery. To assess performance, error prevention is emphasized. The 
objective here is - to be better than others. To assess mastery, perfection and improvement of skills of individual are emphasized, focusing on the learning process, rather than graduation. This system of assessment provides feedback on students' growth, promotes encouragement, motivation, interests and the pleasure of learning (Beghetto, 2005). In the study course Business Planning for the Open Market evaluated both - performance and mastery have been evaluated.

Substantial part of the study involves the assessment of creative actions of Bachelor level students during EAR. Three forms of assessment of novel and adaptive thinking as the construct of creative actions were adopted - diagnostic assessment, formative assessment and summative assessment (Kapenieks, 2010a; Kapenieks \& Salite, 2012):

Diagnostic assessment demonstrates students' ability as a basis for planning a solution (Russ, 2003). The author of the study takes into account how students adapt pillars of creativity - novelty and value.

Formative assessment gathers evidence about students' progress, evaluating novel thinking and adaptive thinking and ensuring that creativity has explicit definition (Beghetto, 2005) and is evaluated by monitoring of progress in each cycle of EAR (Black, 2004). In the study author identified students' progress by content analysis of the students' texts.

Summative assessment allows the evaluation of achievements of each student at the end of the course. It was realized by evaluating novel solutions of problems at the final exams.

The most important advantage of such an assessment system is the possibility to focus on students' creative skills. It also allows evaluating large amounts of information, because most of the work is performed by sudents, who assess their groupmates' work and add their own opinion of the common work, tutorials, additions and corrections of students' work. The process of evaluation becomes exciting, decreasing stress, promoting imagination and creativity of students.

Encouraging factors are uncommon technical solutions and unusual tasks as well (Ferrari 2009). Decrease of social competition is important benefit. Students do not need to compete with each other, as they benefit from the efforts to improve their performance by cooperation.

\section{Characteristic Parameters of Creative Thinking}

According to the goals of the research, parameters for indication of the novel and adaptive thinking competence have been defined. These parameters are necessary for research of correlations between bachelor student expressions of creativity and final assessment in the course. Parameters of creativity are used to research students' mutual influence to express novel ideas in the group during educational action research in internet.

To evaluate learning efficiency and creativity, the following parameters were used as a result of content analysis of the students' opinions and comments:

- Discourse - the number of novel ideas expressed in complementing the peer performance and creating the living theory. The author attributes novel and adaptive thinking to the discourse since the result is something new which in the given case are the new ideas expressed by the students. In the study term "discourse" is used as a name of a parameter, but there is no contradiction 
with the philosophical term. Content analysis is used as a qualitative method deconstructive reading of texts (Olson, 1995). The discourse in which the students complement their groupmates' ideas corresponds to the criteria of novel thinking since it is created by thinking of "what might happen" and not of what has already happened. This parameter characterizes novelty on one hand, and ability to adopt others' novel ideas on other hand.

- The number of discursive ideas in the living theory reflects the number of the student novel ideas and the number of his groupmates' complementary ideas The process of evaluation becomes exciting, decreasing stress, promoting imagination and creativity of students.

- Assessments - the final assessment for acquisition of the study course.

In the study, the discourse is the main parameter, characterizing Bachelor students' creativity.

\section{Characteristic Parameters of Design Mindset}

Design mindset competence reflects ability of constructive thinking of individuals.

Evaluations include skills to expose their thinking and action process to the pursued objectives. In the study, constructive mindset in the study is defined as ability to represent and develop tasks and work processes for desired outcomes (Davies, 2011). The author of the study developed the following characteristic parameters of design mindset:

- Awareness of the objectives,

- Compliance of tasks to be carried out with the objectives,

- Conformity of reachable performance indicators with the objectives.

After completion of the course, the author of the study has evaluated parameters for assessment of design mindset, analysing content of a business idea, content of additions to the groupmates' business ideas and content of living theory, as well as assessed the following factors:

- Clear definition of problem to solve,

- Clear definition of goals to meet,

- Clear description of solution as intermediate targets,

- Appropriate structure of explanation,

- Clarity of explanation.

Each factor was evaluated as zero or one point. Parameter for evaluation of the design mindset of each student during action research in internet environment is sum of mentioned values. Minimum sum is zero, maximum - five points.

\section{Research}

\section{Design of Research}

The goal of the study is identification of the mutual student influence among students, working in the group, expressing future competencies - novel and adaptive thinking and design mindset. The author evaluated expression of novel and adaptive thinking during EAR and design mindset evaluation parameters and assessed performance of students in this competence. Students' mutual influence in groups was expected, and the author evaluated that as well. 


\section{Evaluation of Creativity}

One of the objectives of the study is to find out how the students' creative performance in action research is related to the quality of course acquisition. Figure 3 reflects the average values of the students' parameters of novel and adaptive thinking - discourse in relation to their final scores for course acquisition according to a 10-point system. The chart shows the students' creativity in developing the living theory in relation to the quality of course acquisition. When the students' performance improved, their value of the novel and adaptive thinking increased. However, the novel and adaptive thinking of the students whose performance was outstanding (assessed by 10 points) was slightly lower than the creativity of the students who had scored 9 or 8 points. Perfect performance does not always mean highest creativity level (Kapenieks, 2011b)

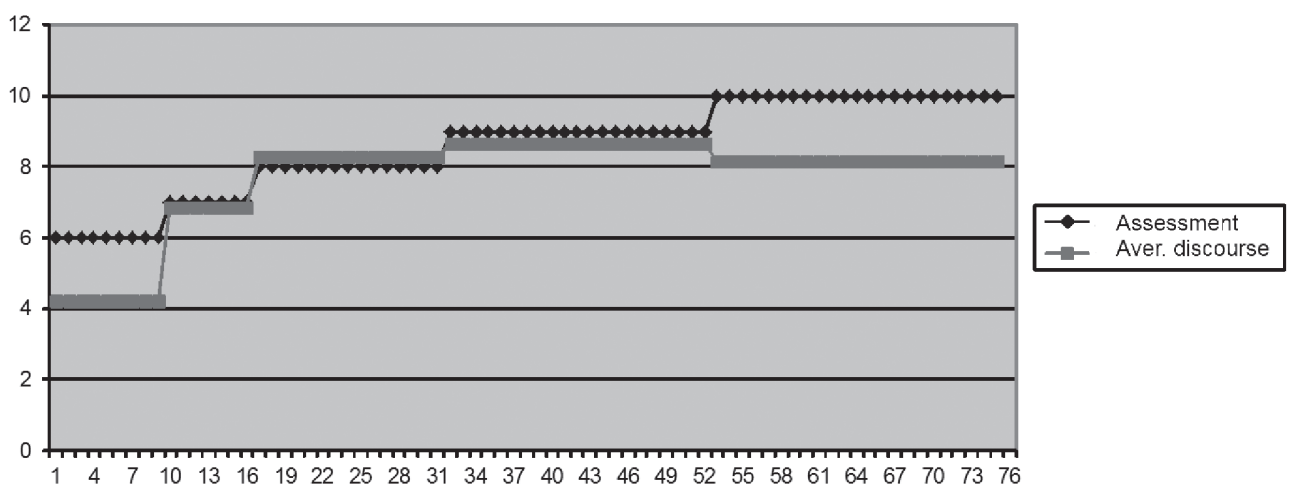

Figure 3. Average values of the students' discourse in relation to their final scores for course acquisition according to a 10-point system. (J. Kapenieks, 2011b)

The author concludes that active involvement in group work in an e-learning environment is rather homogeneous, groups do not produce leaders. Homogeneity is reflected also in the chart offered in Figure 4, which shows that the number of the students' discursive ideas in the living theory is related to the sequence of their involvement in group work.

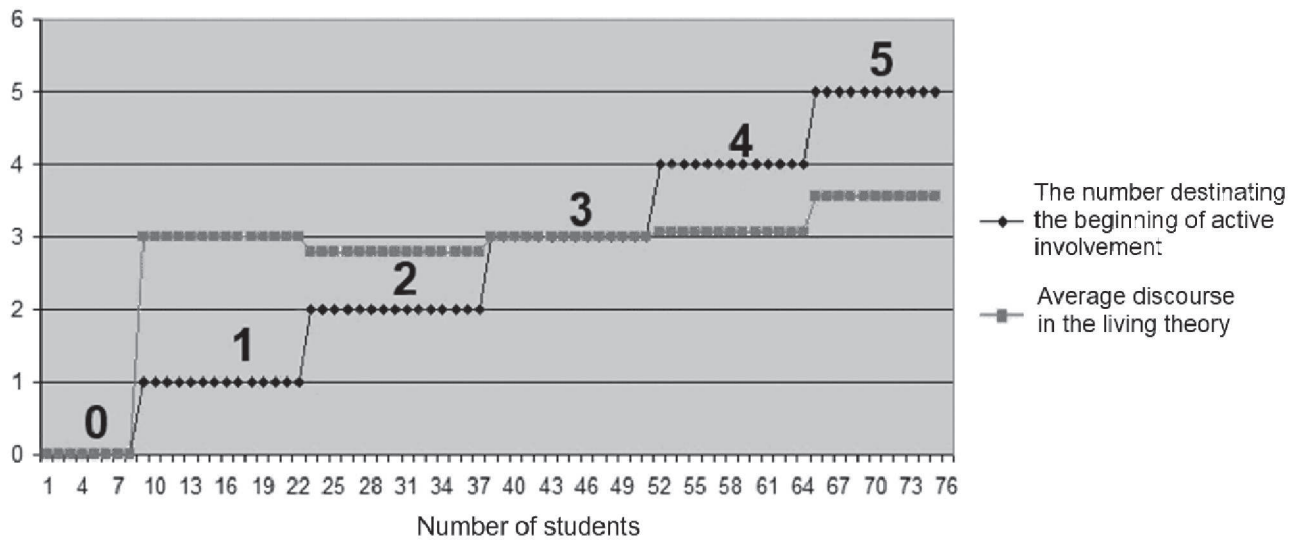

Figure 4. Students' novel and adaptive thinking depending on the sequence of their involvement in group work. (J. Kapenieks, 2011b) 
Figure 4 shows that on the average the students' discursive ideas do not depend much on the sequence of the students' involvement in group work. It indicates their independence which is rooted in their motivation. It was predicted that those students who get involved in group work rather late would be influenced by the ideas expressed by the more active students. The analysis of the content of texts written by the students showed that they did not have the tendency to repeat the ideas expressed by their groupmates but they often either approved of them or rejected them. There were no distinct leaders in the groups, each group member's work was individual and at the same time it was connected with the performance of other group members. However, out of all the target groups nine students $(12 \%)$ did not participate in the discussions.

Some changes in the students' personal beliefs and interests were revealed by the research of the dynamics of students' interest in acquiring the whole business course, in which the action research method was applied.

\section{Evaluation of Design Mindset}

One of goals of the study is to evaluate student's design mindset, as one of most significant competence, when experessing new ideas during educational ection research. Research allowed assessing students' mutual influence in the group. Content and form of students' business ideas, additions and living theories was analysed and desingn minset evaluated, as described above.

The study assessed students' design mindset in accordance with the time period of involvement in the EAR. Design mindset was evaluated for each of 100 students, divided in 20 groups. Then average parameter, characterizing design mindset, was calculated for each group.

Figure 5 shows the average value of the parameter, characterizing design mindset of students according to the sequence of creating groups, showing the sequence of involvement of students in the EAR.

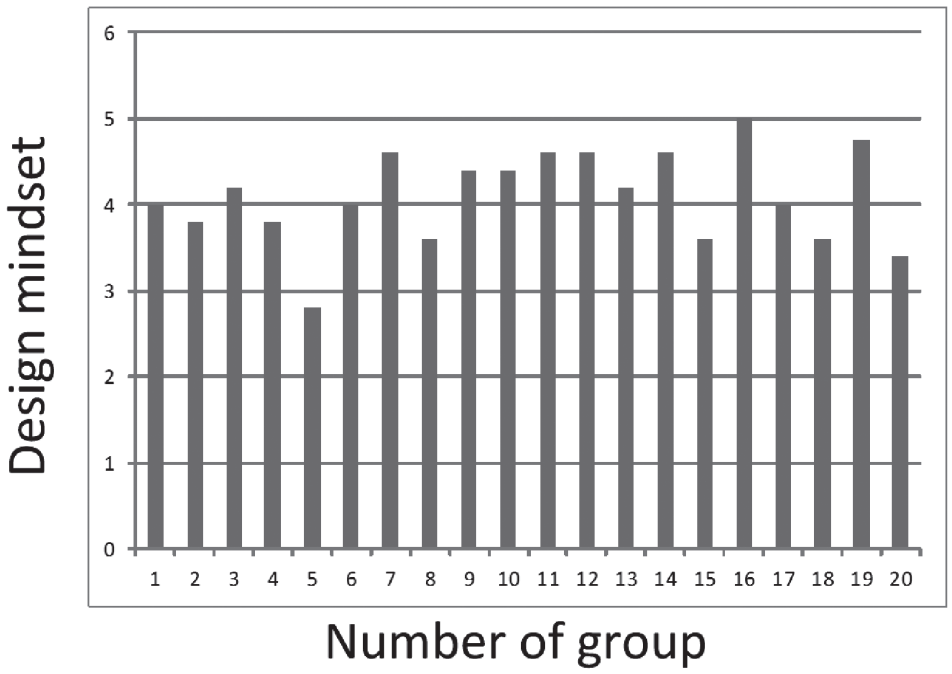

Figure 5. Average assessments of design mindset in groups in relation to the sequence of the student's involvement in work 
Figure 5 demonstrates only a very small relationship between students' activity, characterized by the sequence of involvement, and average design mindset of individuals. Parameters of design mindset are slightly smaller for students, involved in EAR at the very beginning and for the late students.

The study showed students' demonstrated design mindset in relation to the sequence of involvement in groupwork (Figure 6).

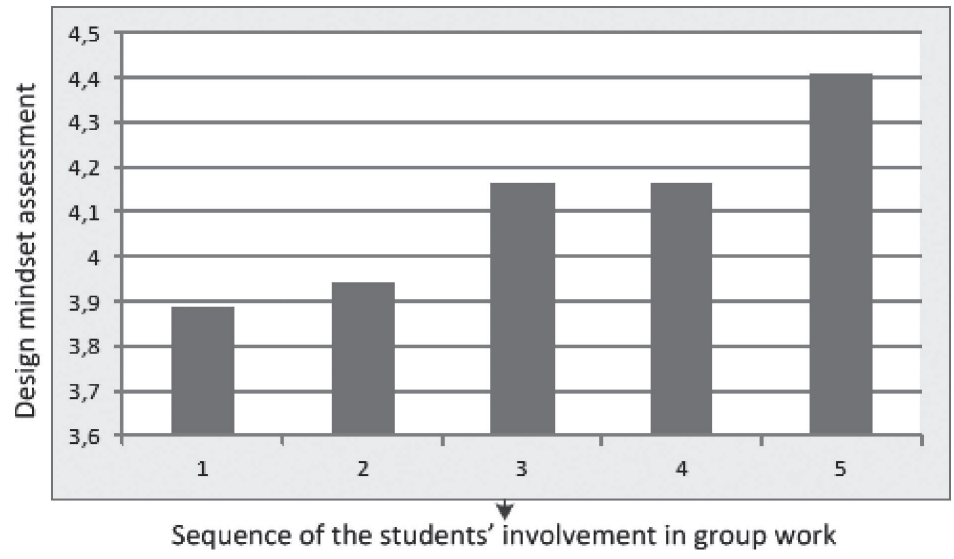

Figure 6. Average assessment of design mindset in relation to the sequence of the student's involvement in a group work

Correlation analysis shows higher average value of design mindset of students, who were involved in groupwork later - the third, fourth or the last. Their explanation was better structured in comparison with the first and second students. It was tested that distribution of students' design mindset values in each group of sequence (first, second, third, fourth, fifth) corresponds to the distribution that allows using arithmetic mean to characterize the assessment of design mindset of students from the group with sufficient credibility. It shows noteworthy influence of the first student to the second student (Pearson Correlation $r=0,47$; sig $=0,037$, correlation is significant at the 0.05 level), dramatically decreasing for third, fourth and fifth student in accordance to the sequence of involvement in group work (respectively $r=0,24$, sig=0,31; $r=0,16$, sig=0,49; $\mathrm{r}=0,045$, sig=0,85).

There are no signifficant correlations between assessment of the second and third, second and fourth, second and fifth student. It allows one to conclude that students are substantially influenced by previous groupmates in the terms of design mindset. Working in Google Disc environment, the performance of the previous student is visible to each subsequent student.

\section{Conclusions and Discussion}

The study shows some developments of students' competencies during the threecycle action research collaborating in internet environment. Students develop reflections, adding supplementary ideas to their groupmates' business ideas and creating their own living theories as the final result. During the action research process students' interests became more oriented to creative acting, more oriented to leadership and interests became 
wider. There is reason to believe that inclusion of educational action research via the internet has a positive influence to the previously mentioned developments in the context of general learning activities of the first year bachelor level students.

The study results have demonstrated homogeneity of group work via the internet, motivating each student to express his/her own novel and adaptive ideas. There was not identified strong leader formation in collaborative groups on the internet, as it typically happens in the face-to-face groupwork. The motivating factor for so high independency in groupwork is transparency of each student's work and additions to the groupmates' ideas. Transparency promotes each member of the group to be active in generating new ideas and proposing substantial inprovements.

The study has demonstrated the influence between members of group in the terms of structuring of expressed ideas, characterizing students' design mindset. It shows substantial influence from written texts that are visible to each member of group. We can conclude that cooperative EAR is an effective tool to develop the participants' individual design mindset as one of key competencies for future.

Within the framework of the study, a new method has been elaborated which allows quantitative assessment of the students' novel and adaptive thinking and design mindset. Action research in an e-learning environment helps the students not only to create knowledge but also to develop their views and interests in a way that enhances their novel and adaptive thinking. During collaboration in the group in internet, students influence each other to express their ideas in the structured way. This tendency corresponds to a system of competencies suitable for most required professions in near future.

The application of new information and communication technologies in EAR in an e-learning environment create opportunities for sustainable development of an individual:

- the information and communication technologies give the possibility to develop the competencies to construct personalised knowledge,

- technological solutions oriented toward the user's needs enable him/her to build personalised experience by way of reflection,

- the mobility of the technologies helps to construct contextual knowledge relevant to the given situation,

- the accessibility and networking of the technologies provide the opportunity to generate knowledge as a discourse collaborating in a discussion.

Educational action research helps improve the students' study process as they generate knowledge themselves by way of cognition and reflection. The generation of knowledge is the result of prototypical thinking. It is based on direct and indirect experience and is open to new experience. The new information and communication technologies provide the opportunity to perform EAR in the form of e-learning. The elaborated research method allows to quantitatively characterising processes related to elusive knowledge which are difficult to express in words. Earlier it was characterised intuitively. EAR in an e-learning environment shows that:

- students are motivated to participate in EAR within the framework of their study course. They are not shy to voice innovative ideas creating a discourse, constructing and acquiring new knowledge. They learn to accept and access other students' ideas, incorporating them in their own statements,

- the use of this method increases the students' interest in the study and improves the acquisition results, 
- EAR supports development of students' novel and adaptive thinking competence as substantial component of future competencies, and it helps to improve the course acquisition results,

- the most creative students in EAR have better results in the study courses acquisition, except those students whose final results are the highest - they are slightly less creative in EAR.

It has been proven that in the course acquisition the students whose academic achievement is the highest are not those who create the largest number of new ideas. However, the deficiencies of the knowledge assessment system have to be taken into account: the highest mark is usually given for perfect acquisition of knowledge instead of the skill to apply it in novel and adaptive way.

In an e-learning environment the EAR makes the traditional e-learning oriented towards problem solving much more creative. Such a learning environment is designed to support research activities and corresponds to the dimensions emphasized by O. Grišāne (Grišāne, 2008): (1) students'individual interests - initial selection of personally significant contexts; (2) ability of university to design such environment for coordination students'and lecturers research work; (3) influence of learning environment to development of students'subjective inquiry toward the aim of sustainable development. Novel and adaptive thinking competence can be characterised by sustainability in contrast to short-term problem solving by adaptation. This feature of EAR in an e-learning environment can be used to support life-long learning and teachers' education for sustainable development.

Cooperation is an essential component of EAR. Group work in an e-learning environment has several nuances that differentiate it from the group work of full-time students, in which usually one or a few students dominate.

- It is easier to supervise students' group work in an e-learning environment during EAR. It is comparatively easy to assess each student's performance in group work.

- Students' performance and creativity in the EAR group does not depend on the sequence of their involvement in group work. Students who join the group as the last members manage to do only little less in comparison with others.

- Intensive work, when the students do not have to wait long for the reaction of their groupmates, stimulates their activity. The supervision and the involvement of the teacher and the e-learning consultant stimulate the students' activity. However, direct involvement and interference into the students' collaboration is not recommended in the EAR.

There were identified both approaches to the developing novel and adaptive ideas during EAR, mentioned by Salite (Salìte, 2008): (1) dilemma approach, suggesting ready - made trials and focusing to proffered solutions - tipical for students' additions to explanations of groupmates' business idea (in some cases it is too simplified and shallow); (2) non-oppositional means, distinquishing factors restrictive for development typical for explanations of personal business idea and living theory.

Mentioned approaches determine some limitations for students' EAR in the internet environment, designed on the Google Disc applications. Difficulties are determined by inadequacy of the environment to organize in-depth an in-depth research on a specific topic. Another limitation, identified by the author, are restrictions, determined by the differences of students' ICT skills. The study was conducted among students majoring 
in information technologies with relatively homogenous ICT skills. The method can cause ICT use difficulties for some of students of humanities or social sciences.

During research the author identified some further implications of research. Important future directions are an in-depth study of users' behaviour in the internet environment during EAR. Such study will allow designing learning environment more personal, adopting to the users' needs. Analysis of users' behaviour could help to improve teacher involvement in the EAR process in more reasoned way, strengthening motivation and improving quality of EAR. It will also allow design EAR for development of improvement of competencies in more focused way that will be necessary in the near future and middle-term future for competitiveness in the labour market and sustainable development.

\section{Acknowledgement}

Research was carried out within the project of European Regional Development Fund New user behavior interpretation algorithms a radical improving knowledge transfer in e-ecosystem (JAUZI).

\section{References}

Amabile, T. (1998). How to kill creativity. Harvard business review, 76(5), 76-87.

Bebre, R. (2003). Kreativitātes psihologijas pètījumi Latvijā. Rīga: RaKa.

Beghetto, R. (2005). Does Assessment Kill Student Creativity? The Educational Forum (69), 254-263.

Binkley, M., et al. (2012). Defining twenty-first century skills. In P. Griffin, et al. (Ed.), Assessment and Teaching of 21st Century Skills (pp. 17-66).

Black, P., Harrison, C., Lee, C., Marshall, B., \& Wiliam, D. (2004). Working inside the black box: Assessment for learning in the classroom. Phi Delta Kappan 86(1), 9-21.

Bloom, B. (1956). Taxonomy of educational objectives. Handbook 1: Cognitive Domain. New York: David McKay.

Cedefop, (2008). Future skill needs in Europe. Medium-term forecast. Luxembourg: Office for Official Publications of the European Communities.

Chapnick, S., \& Meloy, J. (2005). Renaissance eLearning. San Francisco: Pfeiffer.

Clark, R. C., \& Mayer, R. E. (2011). e-Learning and the Science of Instruction: Proven Guidelines for Consumers and Designers of Multimedia Learning: Wiley.

Cohen, L., \& Ambrose, D. (1999). Adaptation and Creativity. In M. A. P. Runco, S. R. (Ed.), Enciclopedia of Creativity (Vol. 1). San Diego, USA, London: Academic Press.

Craft, A. (2005). Creativity in schools : tensions and dilemmas. London: Continuum.

Davies, A., Fidler, D., \& Gorbis M. (Ed.). (2011). Future Work Skills 2020: Institute for the Future for the University of Phoenix Research Institute.

Davis, G. (1999). Barriers to Creativity and Creative Attitudes. In M. A. P. Runco, S. R. (Ed.), Enciclopedia of Creativity (Vol. 1, pp. 165-185). San Diego, USA, London: Academic Press.

Dewey, J. (1916). Democracy and Education. New York: The Macmillan Company.

Dick, B. (2009). Theory in action research. Action research, 7(5), 5-12. 
EC. (2008). Lifelong Learning for Creativity and Innovation. A Background Paper. Slovenia: Slovenian EU Council Presidency.

EC. (2008a). The European Framework for Lifelong Learning (EQF). Luxembourg: Office for Official Publications of the European Communities Retrieved from http://ec.europa.eu/education/pub/pdf/general/eqf/leaflet_en.pdf

ELGPN. (2014). European Lifelong Guidance Policy Network. Retrieved May 5, 2016, from http://www.elgpn. eu/elgpndb/search/metadata/view/251

Ferrari, A., Cachia, R., \& Punie, Y. (2009). Innovation and Creativity in Education and Training in the EU Member States: Fostering Creative Learning and Supporting Innovative Teaching. Retrieved from http://ftp.jrc.es/EURdoc/JRC52374_TN.pdf

Glaser, B., Strauss, A. (1967). The discovery of grounded theory: Strategies for qualitative research. Chicago: Aldine.

Grišāne, O. (2008). Designing environment for research and learning in secondary school. Journal of Teacher Education for Sustainability, 10, 17-31.

Grundspeņkis, J., Anohina, A. (2005). Agents in Intelligent Tutoring Systems: State of the Art. RTU zinātniskie raksti, 5.

Guilford, J. (1967). The nature of human intelligence. New York: McGraw-Hill.

Iliško, D. (2007). Teachers as agents of societal change. Journal of Teacher Education for Sustainability, 7, 14-26.

Kapenieks, A. (2009). Zināšanu sabiedrības tehnologiijas un jaunā mūžizglìtība. Latvijas vēsture, 1(73), 6-14.

Kapenieks, J. (2010a). Empowering users by applying the action research approach in e-studies. Paper presented at the eLearning Baltics 2010, Rostock, Germany.

Kapenieks, J. (2010b). Action reserch for creating knowledge in e-learning environment. Paper presented at the 8th International JTEFS/BBCC conference "Sustainable development. Culture. Education", Paris, France.

Kapenieks, J. (2011b). Collaboration trends during action research in an e-learning environment for developing and acquiring effective personal knowledge. Paper presented at the CSEDU 2011 3rd International Conference on Computer Supported Education, Noordwijkerhout, The Netherlands.

Kapenieks, J., \& Salīe, I. (2012). Action reserch for creating knowledge in e-learning environment. Journal of Teacher Education for Sustainability, 14(2), 111-129. DOI: $10.2478 / \mathrm{v} 10099-012-0012-\mathrm{x}$.

Kevin Barge, J., \& Fairhurst, G. (2008). Living leadership: A systemic constructionist approach. Leadership, 4(3), 227-251.

Koestler, A. (1964). The act of creation. New York: Penguin Books.

Kostuolas - Makrakis, N. (2010). Developing and applying critical and transformative model to address education for sustainable development in teacher education. Journal of Teacher Education, 12(2), 17-26.

Lefrançois, G. (2000). Psychology for Teaching. Belmont: Wadsworth.

Lewin, K. (1946). Action Research and minority problems. Journal of Social Issues, 2(4), 34-46.

NACCCE. (1999). All our futures: Creativity, culture and education. Report to the Secretary of State for Education and Employment the Secretary of State for Culture, Media and Sport. Retrieved May 6, 2016, from http://sirkenrobinson.com/pdf/ allourfutures.pdf 
Oldham, G., \& Cummings, A. (1996). Employee creativity: Personal and contextual factors at work. Employee Creativity: Personal and Contextual Factors at Work, $39(3)$.

Olson, H. (1995). Quantitative 'versus' qualitative research: The wrong question. Retrieved May 9, 2016, from http:/www.ualberta.ca/dept/slis/cais/olson.htm

Runco, M. (2003). Education for creative potential. Scandinavian Journal of Educational Research, 47(3), 317-324.

Russ, S. (2003). Play and creativity: developmental issues. Scandinavian Journal of Educational Research, (3), 291-303.

Salite, I. (2008). Educational action research for sustainability: Constructing a vision for the future in teacher education. Journal of Teacher Education for Sustainability, 10, 5-16.

Salìte, I., Mičule, I., Kravale, M., Iliško, Dz., \& Stakle, A. (2007). Towards the sustainability in teacher education: promise of action research. Education and sustainable development, 2.

Salmon, G., Nie, M., \& Edirisingha, P. (2010). Developing a five-stage model of learning in Second Life. Educational Research, 52(2), 169-182.

Simplicio, J. (2000). Teaching classroom educators how to be more effective and creative teachers. Education, 120(4), 675-680.

Sternberg, R., \& Lubart, T. (1999). The concept of creativity: Prospects and paradigms. In R. Sternberg (Ed.), Handbook of creativity (pp. 3-15). Cambridge: Cambridge University Press.

Štāle, G., Slaidiņš, I., \& Kapenieks, A. (2005). New approach of e-learning solutions for empowerment of people in regional development context. Paper presented at the ICTE in Regional Development: Annual Proceedings of Vidzeme University College, Valmiera, Latvia.

UNESCO. (2011). ISCED: International Standard Classification of Education. Retrieved May 7, 2016, from http://www.uis.unesco.org/Education/Pages/internationalstandard-classification-of-education.aspx

Whitehead, J. (2009). Generating living theory and understanding in action research studies. Action Research, 7(1), 85-99.

Williamson, B., \& Payton, S. (2009). Curriculum and teaching innovation. Retrieved May 9, 2016, from http://archive.futurelab.org.uk/resources/documents/handbooks/ curriculum_and_teaching_innovation2.pdf

Correspondence concerning this paper should be addressed to Jānis Kapenieks, Dr. Paed. Distance Education Study Centre, Riga Technical University, Kronvalda bulv. 1, Riga, LV-1010, Latvia. Email: janis.kapenieks@gmail.com 